\title{
Postcolonial Youth in Contemporary British Fiction
}

\author{
Laura María Lojo-Rodríguez, Jorge Sacido-Romero and Noemí \\ Pereira-Ares
}

1

Yes, We Can

We would like to begin by both questioning and justifying the legitimacy of our position of enunciation as scholars in the field of Postcolonial Youth in Contemporary Fiction announced in the title. ${ }^{1}$ None of the contributors to this multi-authored volume falls any longer under the age category of "youth" or "adolescence", and all but one lack any credentials to be considered "postcolonial", a term whose currency we defend. So, it seems we are speaking for the Other, instead of letting the Other-or as Gayatri Spivak put it (1988), "the subaltern"-speak. Yet, while this Other has expressed itself in the major contributions of postcolonial critics and theorists who have changed the landscape of cultural knowledge and whose voice informs all of the chapters collected in this volume, something different is the case with the young.

For decades now, this silencing of the young has been brought to the fore by authors who contest the dominant approach which treats young people not as subjects on their own but as adults in the making. Childhood and youth are often seen as preparatory stages in a biological and social process oriented towards adulthood, the telos of this process and the acquisition of which is the mark of a full-blown individual. This developmental view is regulated by the adult gaze and episteme which deprive children and youths of sociocultural relevance, influence, meaning or agency, as if they contributed nothing to, or provided no insight into, historical change, which is presumably led by adults from an unassailable and stable position of power - a double perspective illusion on the direction the world is or may be taking. Thus, for instance, Charlotte Hardman complained long ago about how anthropological discourse treated children as one of the “'muted groups' i.e. unperceived or elusive groups (in terms of anyone studying a society)" (1973, 85). In the wake of Hardman and

1 Georgie Horrell states that an act of self-interrogation is imperative for both writers and critics of postcolonial fiction featuring young characters: "the postcolonial writer (or critic of children's literature) is [...] in a doubly delicate position which requires a highly critical and yet fluid self-reflectivity" $(2012,48)$. See also Nilan and Feixa $(2006,5)$. 
others (MacKay 1973), Allison James and Alan Prout sketched a new paradigm for the sociology of children as an alternative to the dominant one in which children were present yet silenced, "as passive subjects of social structures and processes" deprived of any active role "in the construction and determination of their own social lives, the lives around them and of the societies in which they live" $(1997,8)$.

Something similar was argued by Mary Bucholtz in relation to how the dominant view on youth as a stage of distress "inevitably frames young people primarily as not-yet-finished human beings" (2002, 529). Bucholtz spoke in favour of a change in perspective concerning the young for whom the "rapid social change [characteristic of our contemporary context] need not be experienced as dramatic or unsettling" and who "are as often the agents as the experiencers of cultural change" $(2002,530)$. The specific manifestations, actions and decisions of the young may be not just sterile or foredoomed reactions of/to distress and disorientation, but also assertive and agential expressions of particular ways of being in the world, which often result in the adoption of specific life-projects of their own making. In paying due attention to young people's world of their own, however, we can obviate neither the coexisting adult world with which they interact, nor the fact that young lives progress in time towards adulthood, the latter understood as culturally diverse modalities of subjectivity which not only shape them as passive products of processes of socialisation, but are also shaped by them as effective agents of social transformation. To the statement of the editors of the Youth in a Globalizing World series concerning adolescence and youth "as valuable barometers of social change", we could add that the young exert part of the transformative social pressure of which they are measuring devices (Cicchelli and Octobre).

This double-edged dynamics in which youngsters are engaged is in line with Mark Stein's main thesis concerning the remarkable presence of the traditional Bildungsroman or "coming-of-age" novel in contemporary "black British literature" (2004). These novels of transformation by postcolonial, diasporic, mixed-raced British authors, Stein argues, work in a double direction. On the one hand, they are fictional renderings of young characters' processes of formation in the passage from childhood to adulthood that trace their struggle with a sense of unbelonging and dislocation through the modalities of subjecthood available to them. On the other hand, these narratives aim at the same time at actively transforming British society and cultural institutions by particularly instilling a sense of critical awareness in potential readers, being thus endowed with a performative power. The formative and the performative, the blunter edge and the cutting edge of the characters' double-edged subjective position are at work simultaneously. 
Stein, a white western scholar like most of us in this volume, lends an ear to the way postcolonial creative writers have (re)imagined the identitary vicissitudes of young characters belonging to ethnic minority groups in Britain with the help of "post-colonial theory and black cultural studies" (2004, xiii). The scope of the present collection of essays is similar to that of Stein's study, though it differs from it in important ways, one of them being the lack of a homogenous theoretical framework applied throughout - something expected in a monograph written single-handed, but not in a multi-authored volume like the present one. Another point of departure from Stein's study relates to the choice of literary corpus, taking into account that the vast majority of the chapters do not discuss novels, but rather concentrate on short stories, a genre whose formal and thematic peculiarities are relevant for our particular approach to the representation of postcolonial youth in contemporary British fiction.

Perry Nodelman famously argued that the representation of children both in child psychology and in children's literature was an "imperialist" act (1992). The same could be said of young characters in literature as projections of the adult mind, not as individuals in themselves. Yet, as we have pointed out, discursive representations of young people, even if produced by adults, need not be adult-centred if they are receptive enough to their peculiarities and idiosyncrasies, which become more prominent in the case of particular individuals as those depicted in fiction. Furthermore, the idea that the stories and novels by postcolonial authors featuring postcolonial young characters are imperialist acts seems dubious, not to say untenable. What about a middle-aged author writing a story about a much older character? Would she or he be accused of illegitimate appropriation? It would be all the more reasonable to say that this is the case, at least taking into account that, as fifty-year-old Irish-Canadian author Emma Donoghue has recently pointed out, "[a]t least with children, you can to a certain extent remember", whereas "[i]f you write characters who are older than you, there's a lot of guesswork" (Brean 2020). Through the work of the imagination based on observation and personal experience, the world of the young can be (re)captured and rendered in fiction. Fiction has its own way of reimagining the past and presenting it to readers. Is, for instance, High Victorian London more fully represented in a historiographical, sociological or anthropological account or in a Dickens novel? Do we get a clear sense of what life was like in the mid-nineteenth-century British metropolis in a history book or in a work of fiction? The answer is that they represent the past differently as they use different codes to communicate meaning. Moreover, should a Spanish, German, French or Austrian literary critic refrain from discussing a novel by Dickens because she or he is not English and/or does not 
live in Victorian London? Let the affirmative answer to this otherwise rhetorical question serve to justify the legitimacy of our position of enunciation as mainly white western scholars studying the representation of postcolonial youth in contemporary British fiction. For our object of study as literary critics is that portion of sociocultural reality that goes by the name "literature" and, through it, to address those literary and extraliterary aspects we deem relevant or interesting.

\section{Life Goes On: Youth, the Postcolonial and Liminality}

It almost goes without saying that human life takes place in time and that its temporal progress both at the individual and collective level is affected by moments of crisis that may, and frequently do, introduce changes in the expected course of development. Hardman was well aware that her proposal of studying children as people "in their own right, and not just as receptacle of adult teaching" meant a change in perspective that entailed a disregard of temporality: "Instead of stressing the diachronic, I want to stress the synchronic" $(1973,87)$. Bucholtz, on her part, does something similar in relation to "youth" when distinguishing the latter from "adolescence" as object of study: "Where the study of adolescence generally concentrates on how bodies and minds are shaped for adult futures, the study of youth emphasizes instead the here-and-now of young people's experience, the social and cultural practices through which they shape their worlds" (2002, 532; emphases added). Adolescents come across in Bucholtz's description as passive objects of adult manipulation as if they did not also contribute to shaping the "adult futures" in wait for them. As to youngsters, the exploration of their peculiarities, capabilities and practices should not be predicated upon the idea that their lives exist in isolation ("their worlds") and arrested time ("here-and-now") as if they were unresponsive to the pressures of the adult world outside and oblivious to the biological and sociocultural aging processes in which they are inevitably engaged.

Though we cannot but welcome studies that bracket off temporality to concentrate on the distinctive features of youth cultures to prevent the latter from being colonised (silenced and rendered invisible) by the adult episteme, we retain the idea that "youth" is a stage in life, in the same way that we envision "the postcolonial" as an important part of a historical period, of our time. Although neither follows a pre-fixed pattern of development, they are nevertheless part of developmental processes whose coordinates they contribute greatly to transform. Even Bucholtz, otherwise very critical of developmental approaches to adolescence, concedes that " $\mathrm{t}] \mathrm{he}$ emphasis on adolescence as 
a universal stage in the biological and psychological development of the individual usefully highlights selfhood as a process rather than a state" (2002, 529; emphasis added). Bucholtz's distancing from developmental theories of adolescence goes hand in hand with her disregard for the notion of "liminality" drawn from classic anthropology (van Gennep 19o9; Turner 1969) that informs these theories as the latter approach "adolescence almost exclusively as a liminal position between childhood and adulthood that is marked in many (but not most) cultures through some type of initiation ceremony [...] in the hands of adult members of the community" $(2002,529)$. She concludes that the value of liminality as a conceptual tool to study youth is undermined or lost in the face of "the disappearance or alteration of these and other age-graded practices" in the contemporary world (Bucholtz 2002, 529). To limit the notion of liminality to the adult-controlled rites of passage practised in traditional communities and what remains of the latter is too narrow a view, as the notion has been disengaged from disappearing sociocultural contexts and expanded to address contemporary issues. Already in Victor Turner's The Ritual Process (1969) we come across lines of argument concerning liminality which are valuable for the approach to postcolonial youth in contemporary British fiction which is the focus of this volume. For instance, Turner's definition of "[1]iminal entities" applies equally well to youngsters and contemporary postcolonial subjects: they "are neither here nor there; they are betwixt and between the positions assigned and arrayed by law, custom, convention, and ceremonial" $(1969,95)$. Moreover, Turner conceives of liminality in temporal terms as a moment of what he calls "anti-structure" - tellingly enough, he subtitles his work Structure and Anti-Structure. Thus, "the liminal period" is the moment in which subjects transgress the hierarchical prescriptions of the social structure and rehearse new forms of identity and human relations from inside of the structure itself, not from some external space of exclusion (the latter would be the place of the marginal) (Turner 1969, 96). It is in this liminal space of anti-structural contestation where the youngsters' agency capable of transforming the status quo is to be located, without losing sight of the fact that they are inevitably placed in a temporal trajectory that leads to adulthood. And the same can be said of "the postcolonial" in our contemporary era, where it has forcefully moved from the peripheral, marginal space it earlier occupied to become a relevant agent of historical progress in an increasingly globalised world. As Robert J. C. Young states: "Far from being over, the twenty-first century is already the century of postcolonial empowerment" $(2012,20)$.

Postcolonialism, as a discourse and as a period, seems to be under permanent crisis - not very much unlike youth or adolescence and their conceptualisations. As Graham Huggan stated, "postcolonialism has come to prominence 
as it lurches into crisis" (2000, 279). Indeed, almost since its inception, postcolonialism has been attacked from multiple fronts, beginning with the debates surrounding the concept itself, a concept which even Spivak herself considered "just totally bogus" (Young 1991, 224). Among the objections raised against postcolonialism, we could mention accusations of complicity with current forms of neo-colonialism made by scholars such as Aijaz Ahmad (1992; 1995) or Arif Dirlik (1994). These critics have found fault with the institutionalisation of postcolonial theory within the Western academe as well as with the privileged position from which leading postcolonial thinkers speak. Likewise, postcolonialism has also been frequently criticised for using Western theoretical paradigms and even for the cryptic vocabulary of its practitioners (Eagleton 1999). But what is even more important, scholars have increasingly questioned the currency of the term to address the complexities of a world characterised by globalisation, transnational fluxes and transcultural exchanges: "Postcolonial theory [might be] a very productive tool for rereading history, but it is entirely insufficient for theorising contemporary global power" (Hardt and Negri 2000, 146). Similarly, amongst literary critics, postcolonial theory has increasingly come to be deemed insufficient to interpret contemporary texts which, although connected to (post-)colonial histories in one way or another, put the emphasis on the condition of living in global, transnational and transcultural spaces.

It is against this background that postcolonialism has been said to have reached a dead end (Hardt and Negri 20oo; Schoene 2009). As John McLeod argues in "Sounding Silence: Transculturation and its Thresholds" (2011), critical discourse has shifted from its previous penchant for the prefix "post"as in post-war, postcolonial, postmodern, postfeminist - to an ever-growing enthusiasm for the affix "trans" as in translational, transnational, transcultural, transethnic or transcolonial. Such a shift answers to the emergence of new realities which, shaped by what Simon During called the "rhythms of globalization" (343) back in 1992, are difficult to interpret under theorisations that give priority to nation-state issues - even though nationality remains an identititary vector that seems to have gained further track in a twenty-first century marked by new debates over national identity and borders. Yet, as McLeod averts, in pursuing new critical paradigms we should be cautious not to send "the wisdom of the old prematurely into cold storage" $(2011,1)$. This is to a certain extent what has happened with postcolonialism: some critics having prematurely proclaimed the death of this field in their urgency to develop new perspectives and vocabularies. No doubt frameworks such as those provided by transculturalism, transnationalism or cosmopolitanism might offer suitable analytical frameworks through which to examine the conditions of our 
current globalised and globalising world, to move away from postcolonialism's privileged emphasis on the nation, and to analyse a contemporaneity that is marked by deterritorialisation, displacement, dislocation, diaspora, transnational circulation and transcultural exchanges. Nevertheless, as scholars such as Stuart Hall (1996), Diana Brydon (2004), Janet Wilson, Cristina Şandru and Sarah Lawson Welsh (2010) or John McLeod (2011) have forcefully suggested, rerouting the focus of postcolonialism, acknowledging its wisdom and/or putting it in dialogue with the epistemology engendered within recent theoretical paradigms, might prove more productive than "pronouncing premature obituaries" (Brydon 2004, 691).

The present volume is framed along these lines as it retains the validity of postcolonialism against its "amnesical dismissal" (McLeod 2011, 3). Apart from the undeniable fact that postcolonial studies have played a crucial role in pushing the marginal into the putative centre in an unceasing struggle for recognition, it cannot be ignored that many recent theoretical paradigms-from transculturalism to cosmopolitanism or globalisation studies-have developed at the expense of postcolonialism, and that their vocabularies often resort to and/or appropriate that of postcolonial theory. Furthermore, adopting a postcolonial lens helps unveil and trace the connection between past, present and future-or, as Edward Said explained, it conveys "a more urgent sense of the interdependence between things" (1994: 72). And, in fact, this is important in the case of many of the literary works dealt with by the contributors to this volume as, at times, we find in the narratives under inspection a movement from a colonial context to the postcolonial metropolis and back again to the by now independent country. It is necessary to remark that the concept of "postcolonialism" and the idea of "the postcolonial" endorsed herein do not denote the existence of a fixed theoretical apparatus; this is no longer possible for, as RobertJ.C. Young maintains, "[s] o many disciplines have been, so to speak, postcolonialized, along with the creation of related subdisciplines such as diaspora and transnational studies, that [...] it [is] difficult to locate any kind of center of postcolonial theory" $(2012,22)$. Postcolonialism or the postcolonial is, rather, understood as a flexible theoretical frame through which to explore disparate realities and trace temporal continuities and discontinuities between past, present and future. The attempt to come up with a finalising definition of the terms "postcolonialism" or "the postcolonial" is foredoomed, beginning with the complexities derived from the ambivalent meaning of the prefix "post" and the question of the "postcolonial hyphen" (Boehmer 2006, 341). In this work, the label "postcolonialism" is preferred, mostly because our emphasis, rather than on a strict historical periodisation (though it is a defining element of a historical period, a "part of the consciousness of our era" [Young 2012, 22]), 
is on the wide range of theories, discourses and critical approaches to writing that have come to be subsumed under this broad heading. This vast array of theories, discourses and critical approaches has enriched the field of the postcolonial, keeping it "dynamic and responsive to change" (Wilson, Şandru and Lawson Welsh 2010, 3). For the postcolonial has been subject to transformation, moving away from traditional conceptions "such as anti-colonial centre/peripheries binary" in our contemporary context in which it "is developing under the impact of, among others, globalization, environmentalism, and various trans-national formations - whether political and economic (such as neo-liberal ideologies), or cultural (the 'transnation', the 'glocal', the 'cosmopolitan')" (Wilson, Şandru and Lawson Welsh 2010, 3; emphasis added). The field of the postcolonial must accommodate new realities such as "diasporic and minoritarian subjectivities" or "metropolitan immigrant communities" (which fiction contributes to making more visible) without "abandon[ing] earlier postcolonial emphases on routes and roots, but rather insert[ing] these within the contemporary context of cosmopolitan globalization and its numerous (dis)contents" (Wilson, Şandru and Lawson Welsh 2010, 3). For, to quote Young once more, "[p]ostcolonial theory has always included the foundational and the anti-foundational at the same time" which, far from being incompatible, can, in a seemingly paradoxical way, reinforce each other $(2012,24) .^{2}$ Hence, the diversity of modalities of subjectivity and agency available to "the postcolonial citizens of the third millennium" such as, for instance, "the choices that members of [...] diasporic communities make [which] are not mutually exclusive; they can choose to be both good Muslim women and active citizens of the British polity, rather than seeing these as alternatives" (Wilson, Şandru and Lawson Welsh 2010, 10).

We envision the postcolonial precisely as a site of fruitful and potentially transformative friction between different identitary variables or sociocultural interpellations, some of them seemingly incompatible as those signalled by Young. The combination of what is otherwise commonly considered just as mutually excluding alternatives requires from postcolonial, diasporic, migrant,

2 The passage is worth quoting in full: "Postcolonial theory has always included the foundational [for instance, the return to the sacred or ancestral land] and the antifoundational [for example, the postmodern celebration of deslocalized hybrid identities] at the same time, indeed, it could be characterized by the fact that it has simultaneously deployed these apparently antithetical positions, a feature entirely missed by those who criticize it either as being too Marxist or alternatively too postmodern, though the fact that it is criticized on both counts is indicative. Suspicions about the foundations of established truths are not necessarily incompatible with, and indeed are more likely to be prompted by, the memories of an empirical, experienced history of colonial rule" (Young 2012, 24; emphases added). 
transnational, multicultural subjects a strong effort of what Laura Simich, Sarah Maiter and Joanna Ochocka called "cultural negotiation" (2009, 255). For these authors, postcolonial subjects are, to a much greater extent than individuals who belong to one culture alone, in a situation of "social liminality" (2009, 255), located in the threshold (limen in Latin) where different vectors interact, vectors that call for these subjects' permanent active engagement in their reconciliation, a process that has no guarantee of success as individuals are beset by conflicts they may or may not be able to solve-hence the reference to the "numerous (dis)contents" of globalisation (Wilson, Şandru and Lawson Welsh 2010, 3; emphasis added). To be, as in the example given above, "both good Muslim women and active citizens of the British polity" is not attained easily, let alone spontaneously. It demands the exercise of cultural negotiation or of what some sociologists have called the "reflective habitus" increasingly present in the contemporary world: "The idea that, for some, reflexivity itself is now a habitual turn suggests that certain contemporary individuals and groups may easily and largely unquestioningly engage in reflexive projects of self (re)construction as a matter of course" (Sweetman 2003, 542-543). Paul Nilan and Carles Feixa (2006) consider this practice of reflective habitus that entails agency and choice nothing less than a/the defining characteristic of youth in a globalising world: "The new emphasis on reflexivity—self-conscious invention and reinvention in the shaping of youth identities-is a much wider feature of global culture now, and all youth engage in it to a greater or lesser degree" (3). For Nilan and Feixa, youngsters' engagement in reflective habitus of self-fashioning is more intense in the case of postcolonial youngsters counting on the example of their choice: namely, "urban middle-class Islamic youth" who embrace "western consumerism" and remain devout Muslims at the same time, showing themselves able to "negotiate between apparently competing identity discourses on offer by filtering, synthesizing, judicious choice" (2005, 2-3). In our view, these processes of identity construction do not only unsettle the adult gaze, do not just undermine adult expectations concerning young people's choices of subjective identification- " [w] hat may seem even contradictory identity discourses to an older generation often do not seem so to youth" (Nilan and Feixa 2006, 2) - but also, in the temporal perspective we insist on adopting here, they lay the foundations of future modalities of adult subjectivity and thus contribute to the historical transformation of social reality. Individual experiences, be them in real life or those depicted in the fictional works discussed in the ensuing chapters, take place in, and are determined by, specific environments and territories. So, when talking about postcolonial youth and the interaction with "social reality", we must not take for granted, as Nilan and Feixa tell us, that "the global eclipses the local" $(2006,3)$. As Joschka 
Philipps has recently stated: "A globally oriented approach to youth and generation [...] needs to be extremely nuanced in reconciling its highlighting of transnational dynamics with the fact that they are experienced locally in very different ways" (2018, 3-4; cf. Nilan and Feixa 20o6, 8). Furthermore, this combination of the global and the local (frequently labelled "glocal") constitutive of the experience of young postcolonial subjects must warn us against doing away too hastily with nationality or nation as one of the identitary vectors to be negotiated by postcolonial subjects. As Loomba, Kaul, Bunzl, Burton and Esty stated in Postcolonial Studies and Beyond (2005), national borders are not that permeable, so that it is dangerous to fall into "a facile or premature model of nationlessness that, however unwittingly, answers to the neoliberal fantasy of a borderless planet" (21). A world without boundaries may or may not be desirable, but it is still the future of an illusion, not yet a reality.

The definition of postcolonial subjects as socially liminal beings that engage in processes of cultural negotiation (Simich, Maiter and Ochocka 2009) comes close to what Biodun Jeyifo long ago called "liminal or interstitial postcoloniality" in reference to modalities of subjectivity exhibited by authors that suited the label "postcolonial":

The interstice or liminality here defines an ambivalent mode of self-fashioning of the writer or critic which is neither First World not Third World, neither securely and smugly metropolitan, nor assertively and combatively Third Worldist. The very terms which express the orientation of this school of post-colonial self-representation are revealing: diasporic, exilic, hybrid, in-between, cosmopolitan. (1990, 53)

As stated above, we defend the validity of "liminality" to define youth as a stage in life, but not just as a phase of disabling distress or passive subjection, but also, and more importantly, as a period of transformative agency and choice. In The "Troubled" Adolescent (2019) - to quote a recent source-Jennifer L. Lovell and Joseph H. White "define adolescence as the culturally constructed and developmental period between the onset of puberty and emerging adulthood" (4). Nilan and Feixa also deal with the imperative issue of periodisation in the introduction to the collective volume Global Youth?, where they begin by pointing out that by "youth" they "refer collectively to a wide chronological scale-young people of both sexes in the age range 12 to 35 (or even 10 to 30 in some countries)" (2006, 1). Though temporal limits are variable, "youth" and its companion term "adolescence" refer to a period of intense crisis and transformation that affects not only the individual or groups directly involved but 
society at large. Within the field of contemporary literature, Georgie Horrell has underlined the affinity linking adolescence to the postcolonial:

The adolescent is precisely located at that point at which the requirement for a liberatory, transgressive narrative is most apposite. Quayson's concept of the postcolonial as the text's participation in a "process" of "coming-into-being and struggles against colonialism and its after-effects" connects meaningfully with the notion of adolescence as a "process" of change. $(2012,47-48)^{3}$

Change, both individual and social, has been singled out as the main feature of liminality, that which representations of and studies on the liminal place the focus on: "Liminality tries to capture the permanent inescapability of transitions and the existential as well as the cultural consequences of such destabilizations. In other words, liminality tries to explain change by dense descriptions of boundary crossings" (Achilles 2015, 35; emphases added). Both adolescence/ youth and the postcolonial can be seen as liminal or interstitial sites where changes of the status quo are, or can be, performed. To use Mark Stein's terms referred to above, youth and the postcolonial perform change while they form themselves.

Youth and the postcolonial are united in that both inhabit a liminal locus where new ways of being in the world are rehearsed and struggle for recognition against the impositions of dominant power structures - they are prominent agents of what Victor Turner called anti-structure. In "postcolonial youth" two liminal dynamics are at work, intensifying each other. Authors such a as Toon van Meijl have stressed the "liminal position of multicultural adolescents" (2013, 205), for, as Jensen and Arnett argue, "for many people [postcolonial youngsters] it is no longer a question of becoming an adult member of one culture but instead of figuring out how to negotiate multiple cultures" (2012, 473). Meenakshi Gigi Durham (2004) compares the liminal position of adolescents to that of transnational immigrants in their effort to construct a sense of identity, of who they are. Yet, when both are combined in single individuals, as is the case with the characters in the narratives discussed in the chapters of this volume, the process becomes more demanding and the crises more acute:

3 Quotation from Quayson taken from: Ato Quayson. Postcolonialism: Theory, Practice or Politics? Cambridge: Polity Press, 200o, 9. 
When adolescence and diaspora occur in tandem, identity formation becomes an even more complex issue. The psychological transition of adolescence, already charged in terms of gender and sexuality, is then imbricated with the conundrums of the other transition - the diaspora identity that demands delicate negotiations of race/ethnicity, nation, class, language, culture and history. For children of immigrant diaspora groups, adolescence is a particularly complex juncture, calling for a sophisticated grasp of cross-cultural dialectics and the sociopolitical dimensions of Otherness that will mark their adult lives.

DURHAM 2004, 140-141

The instances of "postcolonial youth" as "[1]iminal entities" (Turner 1969, 95) featured in the corpus of fiction selected for analysis in this book are, indeed, extremely variegated: there are characters who inhabit a postcolonial context or, more particularly, a postcolonial metropolitan centre; characters who have lived experiences which are, in one way or another, linked to a previous colonial past via their multiple "routes/roots" (Gilroy 1993, 19); characters that face the inequalities of a neocolonial present and characters that find themselves falling outside of a hegemonic racial matrix and negotiating a liminal position at the crossroads of ethnicity, gender, class and their intersections in the "diaspora space" (Brah 1996, 209).

\section{Genre Matters}

As pointed out at the end of the first section, fiction has its own way of articulating what life is like in particular sociohistorical contexts which is different from that of other types of texts that follow their specific discursive codes. The present volume focuses on what it is like to be a postcolonial youngster in contemporary Britain as rendered in fictional works. However, even in the field of fiction generic distinctions should be established as novels and short stories (single or in collections), though related, possess different characteristics and capabilities to convey to the reader the experience of the characters they feature. There is a dominant tendency in approaches to youth in fiction to take for granted that fiction - or, even, "literature" for that matter-means "novels". From, say, Norman Kiell's The Adolescent through Fiction: A Psychological Approach (1959) to Mary Hilton and Maria Nikolajeva's edited volume Contemporary Adolescent Literature and Culture: The Emergent Adult (2012) and through Mark Stein's Black British Literature: Novels of Transformation (2004) or Roberta Seelinger Trites's Disturbing the Universe: Power and Repression in Adolescent Literature 
(2000), the choice of corpus is basically novelistic. Thus, the reader comes across frequent references to, for instance, James Joyce's A Portrait of the Artist as a Young Man (1916) as a prominent example of Bildungsroman but there is no mention of "The Sisters", "An Encounter" or "Araby", the first three pieces in Joyce's short story collection Dubliners (1914), which contain memorable depictions of young characters. One reason for this is that longer narratives give enough space for more detailed accounts of processes of transformation affecting individual characters as they develop in lengthier timelines and interact with the sociohistorical context in which they are embedded. Connected to this is the literary debt of fictional representations of youth to the subgenre of the Bildungsroman, the novel of formation or coming-of-age novel. Certainly, the novel is an apt vehicle to render the experience of postcolonial youth. To wit, Stein's magisterial study on the novel of transformation or Blanka Grzegorczyk's contribution to the present volume, which revises the novelistic output of writers such as Vanessa Altin, Sita Brahmachari, Richard MacSween or Nikesh Shukla featuring teenagers who deal with the trauma of terror and war and progress towards moments of resilience and recovery.

Though not absent from the corpus of works, novels do not constitute the major focus of concern in the present volume. Part of the originality of this book lies in the fact that it gives special attention to the ways short fiction depicts the experience of postcolonial youngsters within the context of present-day Britain. Except for Blanka Grzegorczyk's chapter, novels in this volume are either read partly as assemblies of stories that can also stand on their own, or in combination with short narratives. Thus, Gérald Préher reads Jamaica Kincaid's Annie John (1985) not as a novel, but as a "short story cycle", a generic category also used by Isabel Carrera-Suárez and Carla Rodríguez-González in reference to Bernardine Evaristo's Girl, Woman, Other (2019), which is a part of their corpus of study along with collections of short narratives. Claire Chambers and Indrani Karmakar do analyse two novels (Sufiya Ahmed's 2002 Secrets of the Henna Girl and Muhammad Khan's 2018 I Am Thunder), but do so alongside short stories by Sufiya Ahmed and Nazneen Ahmed. So, to a good extent, this volume is conceived also as a contribution to the recent reassessment or revaluation of the short story as a genre in its own right, deserving a greater degree of attention and recognition than it is normally given, particularly in contrast with the novel which dominates the field of fiction as the genre endowed with literary prestige. With no intention to elaborate on the analogy and come to far-fetched, untenable conclusions, the way in which both postcolonial studies and youth studies struggle to render visible and audible what is otherwise invisible and silenced resembles the aim of short story criticism in conferring upon the short form the status of a distinct, distinguishable and 
distinguished literary genre. Claire Chambers, a contributor to the present volume, and Shital Pravinchadra have recently noted how in postcolonial literary criticism "the novel poetry and to some extent drama remain the literary modes of choice, while genre fiction, nonfiction and short fiction receive relatively little attention" (2018, 342); and tellingly enough, works such as Sarah Ilott's New Postcolonial British Genres: Shifting the Boundaries (2015) do not engage with the short story. Even when Mark Stein, on the very last page of his monographic study, warns about the dangers of concentrating on novels and on a few marketed black British authors "at the expense of drama and poetry", he forgets the short story despite the fact that writers such as Hanif Kureishi have been great practitioners of the form for decades $(2004,183)$. Bettina Jansen's Narratives of Community in the Black British Short Story (2018) fills in the blank partially as a book-length study based on "the contention that the short story format invites a higher degree of experimentation with alternative forms of communal belonging than, for instance, the widely studied black British novel" (20). Jansen, another contributor to this volume, does not deal with young people in particular or the question of development/transformation in the way Stein does, but her approach is valuable and must be mentioned in this respect.

Short stories by postcolonial authors can also depict youngsters' processes of transformation, but instead of offering characters' development in full as novels do, they concentrate on critical moments of transition, thus narrowing down the temporal scope and being much more selective in terms of narrative detail. The short story's "brevity and episodic structure", writes Jochen Achilles, "privilege the depiction of processes of transition, threshold situations, and fleeting moments of crisis and decision" (Achilles 2015, 41). The short form requires a more active engagement from readers (Korte 2003, 5; Simpson 2012, $\mathrm{xxv}$ ) and the effect on the latter is sharper and more memorable, eliciting a different kind of responsiveness to the predicament of postcolonial, migrant or diasporic populations than that of longer narratives.

Indeed, one of the most relevant recent developments in short story theory and criticism has been precisely the connection between short fiction and liminality. The formal and thematic hybridity which characterises the contemporary short story makes the form a borderline narrative which combines rhetorical strategies from different genres and whose brevity remains its sole identifiable defining feature. The genre's interstitial nature and its resistance to comply with identifiable categories fosters the emergence of sites for critical reflection and social contestation that spring from the genre's borderline nature. As such, the urgency and efficaciousness with which the short story critically responds to topical issues in our contemporary society may rest on 
its liminality and on the contradictory nature of borders themselves, built to simultaneously "separate and divide on the one hand, and to welcome and allow passage on the other" (Manzanas 2007, 9), inviting us to consider their porous and fluid nature. Thus, "borders", "thresholds" and "interstices" may entail, precisely because of their indeterminacy and their position at a physical, cultural and ideological crossroads, a useful tool of mediation, particularly appealing in an age of "global mobility, digital networking, and interethnic transnationality" (Achilles and Bergmann 2015, 3).

Because borders and interstices question clear-cut divides and definitions through their articulation of fluid alternatives, the contemporary short story emerges as a powerful site to problematise the "representation of liminal identities" and conflictive subject positions, therefore speaking "directly to and about those whose sense of self, region, state or nation is insecure" (Hunter 2007,138 ). This sense of insecurity and cultural alienation is particularly acute in the case of the postcolonial subject, for whom the short story often emerges as an "expressive medium for themes of fragmentation, diaspora and identity" (March-Russell and Awadalla 2013, 3). The interstitial, borderline quality of these narratives has the power to question established assumptions and, in so doing, they pose forward new possibilities which eventually mirror the complex, liminal nature of the postcolonial subject and his/her identity. As Paul March-Russell and Maggie Awadalla suggest, the short story's potential capacity for dissidence is enhanced by its "ambiguous cultural position": on the one hand, the short story's flexibility has ostentatiously made the form a "commercial product residing in popular magazines and sub-literary genres"; on the other, the genre is also perceived as an "artistic medium praised by writers for its technical difficulty and associated with small-press, avant-garde or counter-cultural titles", being simultaneously a product of mass and minority culture $(2013,4)$.

But it is precisely because of such a defiance to categorisation, tension and liminality that the short story is rich in terms of possibilities: following Gilles Deleuze and Félix Guattari, Adrian Hunter has recently suggested that the short story could be regarded as an example of "minor literature", or of that which a "minority constructs within a major language" (Hunter 2007, 219). In this sense, the process of deterritorialisation which Deleuze and Guattari had considered as one of the major subversive strategies operating at different levels in minor literatures has become one of the dominant traits of the contemporary short story's dramatisation of a sense of dislocation and alienation from dominant culture for the postcolonial subject (March-Russell, 148). Such a sense of dislocation and estrangement so often present in postcolonial short stories allows the genre to negotiate with both their native culture and the 
remains of the dominant one in ways which are both critically challenging and formally inspiring.

Likewise, Paul March-Russell has argued how postcolonialism shares with the short story its "undefinable quality" (2009, 247), which relates to the concept of "hybridity" inherent to both terms. Formally speaking, the short story amalgamates different genres serving its own purpose-"a form of bricolage [...] working upon the remains of culture" (248) — but in the case of the postcolonial short story, such an amalgamation of motifs, topics, voices and traditions ultimately entails the subversive purpose of working against an oppressive system while simultaneously validating cultural traditions that have been suppressed by the dominant culture. Ultimately, the short story's formal hybridity, its nonhomogeneous, anti-essentialist nature, seems to be a form that particularly welcomes heterogeneity, openness and renegotiation of similarly hybrid and undefinable identities.

The present volume is divided into four major parts, each of them grouping together contributions that reveal shared concerns and conceptual affinities, even when this four-part division runs the risk of occluding the multiple points of suture that link the twelve articles that make up this book. Thus, Part 1, "Youth, Home and Belonging", includes three chapters that address the way in which diasporic writers have placed the figure of the (emergent) adolescent at the centre of these short stories, which delve into the meaning of home, belonging and community. In the first chapter, Laura María Lojo-Rodríguez reads Andrea Levy's work as a fictionalisation of the Jamaican diasporic experience, the obstacles these immigrants encountered in their way towards integration into Britain and, above all, the frustration they suffered when confronting their own romanticised view of the colonial motherland. More particularly, Lojo-Rodríguez provides a close reading of Levy's "Deborah" (2014), a short story in which identity conflicts are rendered alongside, or in combination with, children's and adolescents' capacity for evil, both a reflection on the flaws and limits of celebrated British multiculturalism. The journey from the Caribbean to Britain is also central to Gérald Préher's discussion in the next chapter, where he engages with the work of Antiguan-American author Jamaica Kincaid. Préher draws on Frank O'Connor's statements about marginal characters in short fiction to argue that the young protagonist in Kincaid's short story cycle, Annie John (1985), is brought to what he calls a "marginal centre", as she remains nostalgically in Antigua, but is physically located in England - the 
Mother Country, from where she revisits critical moments in her life. This self-portrait in retrospect, as Préher argues, reveals that Annie's identity conflicts are as much related to her country's history as a former British colony as to her problematic relationship to others-including her mother, but also her female peers. Moving the focus from the Caribbean to the South Asian diaspora, Carmen Lara-Rallo discusses the position of double liminality occupied by the adolescent characters in "Sophocles' Chorus" and "Mumtaz Chaplin", both included in Roshi Fernando's Homesick (2012), a collection of interlinked stories whose very title anticipates the tension between home and abroad, Sri Lanka and Britain, that impinges on the fictional youths here analysed. Drawing on Victor Turner's anthropology of liminality, Lara-Rallo examines the rites of passage experienced by the young characters in the above-mentioned stories with an eye on the type of adults they become later in the collection.

Part 2, "Youth, Nation and Narration", collects chapters which, exploring a variety of genres and sub-genres, are more attentive to how narrative techniques and strategies are used to articulate issues of national identity and citizenship that continue to affect postcolonial youths. In the first chapter, Isabel Carrera-Suárez and Carla Rodríguez-González examine the portrayal of racialised children and adolescents in works ranging from the life narratives collected in Tangled Roots: True Life Stories about Mixed Race Britain (2015) to Jackie Kay's short story writing and, finally, Bernardine Evaristo composite novel Girl, Woman, Other (2019). Whilst registering the increasing tendency towards transnational and cosmopolitan identity formations, Carrera-Suárez and Rodríguez-González explain that, far from offering an over-celebratory account of mixed-raced subjectivities, the texts under scrutiny problematise the process of growing up multiply from various angles and, in so doing, they bring to the fore debates on such crucial issues as authenticity, belonging and the meaning of "Britishness". The focus on the construction of mixed-raced subjectivities continues in the next two chapters which deal particularly with young adult fiction - from fantasy tales to short stories with magic realist touches. Thus, Laura Torres-Zúñiga examines how Jamila Gavin's fantasy tales in The Magic Orange Tree and Other Stories (1979) and Blackberry Blue and Other Fairy Tales (2013) produce portrayals of childhood and adolescence which, endowed with both a pedagogical and performative function, are aimed at counteracting cultural syncretism. Particular configurations of chronotopes, inflections of the role of paternal figures, or articulations of the politics of fantasy and gender allow Gavin to provide a kaleidoscopic insight into multicultural diversity. Engaging with another author of South Asian origin, Isabel M. Andrés-Cuevas analyses two short stories from Ravinder Randhawa's collection Dynamite (2013). Focusing on the representation of young female 
characters, Andrés-Cuevas explores how British Asian adolescents negotiate their hybrid identities in the face of conflicting social and parental demands. Occupying a liminal position between cultures, these young female characters figure as both objects of patriarchal subjection and heralds of sociocultural change - a change that, at times propelled by magic realist experiences, points at the persistent need to redefine ossified notions of cultural and national identity.

Building on the notion of liminality as a feature of both the short story genre and postcolonial subjectivity, the chapters in Part 3, "Youth, Dislocation and Transformation", sharpen the focus on identity conflicts in adolescence and emerging adulthood; and, when read alongside one another, the articles included herein reveal how contemporary diasporic writing has been moving from an ethnic to a post-ethnic aesthetics. Thus, Jorge Sacido-Romero builds on Erik H. Erikson's work and subsequent amplifications of his theory to produce a psychologically informed analysis of Hanif Kureishi's "Touched" (2002), Leila Aboulela's "The Boy from the Kebab Shop" (2001) and Diriye Osman's "Shoga" (2013). As fictional renditions of multicultural adolescence, Sacido-Romero contends, these texts portray characters that go through a period of "psychosocial moratorium" which entails complex negotiations along ethnic, religious and gender lines. Continuing with Leila Aboulela, Karima Thomas draws on the analogy adolescent-colonial subject to analyse a cycle of three stories where Nadia, a character that appears in Aboulela's Coloured Lights (2001) and Elsewhere Home (2018), features as the protagonist. According to Thomas, Nadia's negotiation of her diasporic status-from childhood to her late teens - results in an awareness of her hyphenated identity and the fluidity of its dynamics, which eventually makes her the embodiment of post-ethnic and transnational cultural models. This predicament ties nicely with the last chapter in this section which, authored by Bettina Jansen, examines the shift from the postcolonial to the post-ethnic in the short fiction produced by black British writers from the 1980s onwards. Jansen's argument is further illustrated through an in-depth analysis of Zadie Smith's writing and, in particular, her short story "I'm the Only One" (200o), where the characters do not fight so much against their in-betweenness, but rather against (white) social expectations and an exclusionary society that insists on difference, rather than on commonality.

The chapters in Part 4, "Youth, Religion and Global Politics", address some of the new challenges faced by postcolonial youths living in twenty-first-century Britain, with the category of "Muslimness" and the events of $9 / 11$ providing thematic suture. Thus, Claire Chambers and Indrani Karmakar discuss the emergence of a renewed sense of religious identification among young 
Muslims in Britain before moving on to an in-depth exploration of the intersections of culture, religion and gender in a number of postsecular Young Adult fictions, including two short stories from the collection A Match Made in Heaven (2020) - Sufiya Ahmed's "Tears and Tantrums" and Nazneen Ahmed's "Ghazal" - as well as two novels: namely, Sufiya Ahmed's Secrets of the Henna Girl (2002) and Muhammad Khan's I Am Thunder (2018). Also engaging with fictions for the young, Blanka Grzegorczyk explores the way in which contemporary writers-Sita Brahmachari, Elizabeth Laird, Bali Rai, Alan Gibbons and Nikesh Shukla, amongst others-have dealt with different modes of terror in the wake of 9/11 and 7/7. Grzegorczyk is interested not so much on what this writing says but in what it does: namely, how it moves beyond terror and trauma through formal devices and patterns whose workings and overall effect the author elucidates throughout the chapter. Finally, the last chapter, authored by Noemí Pereira-Ares, brings together terrorism, Islamophobia and the Brexit referendum through the analysis of the social and psychological anxieties affecting the teenage protagonists of Nikesh Shukla's "We Who?" and Yasmin Rahman's "Fortune Favours the Bold", both published in the anthology A Change is Gonna Come (2017). The chapter, like all the preceding contributions, provides evidence of the ability of literature - and the short story genre, in particular-to swiftly respond to a rapidly changing world as well as to the new socio-cultural realities and conflicts affecting our current global order and the generations to come.

\section{Works Cited}

Achilles, Jochen. 2015. "Modes of Liminality in American Short Fiction: Condensations of Multiple Identities." In Liminality and the Short Story: Boundary Crossings in American, Canadian, and British Writing, edited by Jochen Achilles and Ina Bergmann, 35-49. New York: Routledge.

Ahmad, Aijaz. 1992. In Theory: Classes, Nations, Literatures. London: Verso.

Ahmad, Aijaz. 1995. "The Politics of Literary Postcoloniality." Race and Class 36: 1-20.

Boehmer, Elleke. 20o6. "Postcolonialism." In Literary Theory and Criticism: An Oxford Guide, edited by Patricia Waugh, 340-361. Oxford: Oxford University Press.

Brah, Avtar. 1996. Cartographies of Diaspora. Contesting Identities. London: Routledge. Brean, Joseph. 2020. "Chronological Appropriation without Sounding Insulting or lame Takes Imagination, Says Canadian Author.” National Post, June 6, 2020. Accessed June 26, 2020. https://nationalpost.com/news/chronological-appropriation-take s-imagination-says-the-canadian-author-of-the-room-emma-donoghue. 
Brydon, Diana. 2004. "Postcolonialism Now: Autonomy, Cosmopolitanism, and Diaspora." University of Toronto Quarterly 73 (2): 691-706.

Bucholtz, Mary. 2002. "Youth and Cultural Practice." Annual Review of Anthropology 31: 525-552.

Chambers, Claire and Shital Pravinchandra. 2018. "Guest Editorial: Postcolonial Past, World Present, Global Futures?" Journal of Commonwealth Literature 53 (3):339-344. Cicchelli,Vincenzo and Sylvie Octobre. n.d. "Youth in a Globalizing World." Leiden: Brill. Accessed June 16, 2020. https://brill.com/view/serial/YGW.

Dirlik, Arif. 1994. "The Postcolonial Aura: Third World Criticism in the Age of Global Capitalism." Critical Enquiry 20: 328-356.

Durham, Meenakshi Gigi. 2004. “Constructing the 'New Ethnicities': Media, Sexuality, and Diaspora Identity in the Lives of South Asian Immigrant Girls." Critical Studies in Media Communication 21 (2):140-161.

During, Simon. 1992. "Postcolonialism and Globalization." Meanjin 51 (2): 339-353.

Eagleton, Terry. 1999. "In the Gaudy Supermarket." London Review of Books 21 (10): 5-6. Gilroy, Paul. 1993. The Black Atlantic: Modernity and Double Consciousness. Cambridge: Harvard University Press.

Hall, Stuart. 1996. "When was 'the post-colonial'? Thinking at the limit." In The Postcolonial Question, edited by Iain Chambers and Lidia Curti, 242-259. London: Routledge.

Hardman, Charlotte. 1973. "Can There Be an Anthropology of Children?" Journal of the Anthropology Society Oxford 4 (1): 85-99.

Hardt, Michael and Antonio Negri. 200o. Empire. Cambridge: Harvard University Press. Hilton, Mary and Maria Nikolajeva, eds. 2012. Contemporary Adolescent Literature and Culture: The Emergent Adult. London: Routledge.

Horrell, Georgie. 2012. "Transgression and Transition." In Contemporary Adolescent Literature and Culture: The Emergent Adult, edited by Mary Hilton and Maria Nikolajeva, 46-59. London: Routledge.

Huggan, Graham. 2000."Reading the Readers:SomeThoughts on the Institutionalization of Postcolonial Theory." In Anglistentag 1999 Mainz: Proceedings, edited by Bernhard Reitz and Sigrid Rieuwerts, 270-287. Trier: wvT.

Hunter, Adrian 2007. The Cambridge Introduction to the Short Story in English. Cambridge: Cambridge University Press.

Ilott, Sarah. 2015. New Postcolonial British Genres: Shifting the Boundaries. London: Palgrave Macmillan.

James, Allison and Alan Prout, eds. 1997. Constructing and Reconstructing Childhood: Contemporary Issues in the Sociological Study of Childhood. 2nd edition. London: Falmer Press.

Jansen, Bettina. 2018. Narratives of Community in the Black British Short Story. Cham, Switzerland: Palgrave Macmillan. 
Jensen, Lene Arnett and Jeffrey Jensen Arnett. 2012. "Going Global: New Pathways for Adolescents and Emerging Adults in a Changing World." Journal of Social Issues 68 (3): 473-492.

Jeyifo, Biodun. 199o. "For Chinua Achebe: The Resilience and the Predicament of Obierika." Kunapipi, 12 (2): 51-70.

Kiell, Norman. 1959. The Adolescent through Fiction; A Psychological Approach. New York: International University Press.

Korte, Barbara. 2003. The Short Story in Britain: A Historical Sketch and Anthology. Tübingen: A. Francke.

Loomba, Ania, Suvir Kaul, Matti Bunzl, Antoinette Burton, and Jed Esty, eds. 2005. Postcolonial Studies and Beyond. Durham, NC: Duke University Press.

Lovell, Jennifer L. and Joseph H. White. 2019. The "Troubled" Adolescent: Challenges and Resilience with Family and Multicultural Contexts. New York: Routledge.

MacKay, Robert W. 1973. "Conceptions of Children and Modes of Socialization." In Childhood and Socialization, edited by Hans Peter Dreitzel, 27-43. London: Collier-Macmillan.

McLeod, John. 2011. "Sounding Silence: Transculturation and its Thresholds." Transnational Literature 4 (1): 1-13.

Manzanas, Ana María (2007). "Border Dynamics: From Terminus to Terminator." In Border Transits: Literature and Culture Across the Line, edited by Ana $\mathrm{M}^{\mathrm{a}}$ Manzanas, 9-33. Amsterdam: Rodopi.

March-Russell, Paul (2009). The Short Story: An Introduction. Edinburgh: Edinburgh University Press.

March-Russell, Paul and Maggie Awadalla (eds.) (2013). The Postcolonial Short Story: Contemporary Essays. London: Palgrave.

Nilan, Paul and Carles Feixa. 20o6. Global Youth? Hybrid Identities, Plural Worlds. London: Routledge.

Nodelman, Perry. 1992. “The Other: Orientalism, Colonialism, and Children's Literature.” Children's Literature Association Quarterly 17 (1): 29-35.

Philipps, Joschka. 2018. "A Global Generation? Youth Studies in a Postcolonial World." Societies 8 (14): 1-18.

Said, Edward, 1994. Culture and Imperialism. London: Vintage.

Schoene, Berthold. 2009. The Cosmopolitan Novel. Edinburgh: Edinburgh University Press.

Simich, Laura, Sarah Maiter and Joanna Ochocka. 20o9. "From Social Liminality to Cultural Negotiation." Anthropology and Medicine 16 (3): 253-266.

Simpson, Helen. 2012. "Introduction." In A Bunch of Fives: Selected Stories, xix-xxviii London: Vintage. 
Spivak, Gayatri Chakravorty. 1988. "Can the Subaltern Speak?" In Marxism and the Interpretation of Culture, edited by Cary Nelson and Lawrence Grossberg, 271-313. Urbana: University of Illinois Press.

Stein, Mark. 2004. Black British Literature: Novels of Transformation. Columbus, OH: The Ohio State University Press.

Sweetman, Paul. 2003. "Twenty-First Century Dis-Ease? Habitual Reflexivity or the Reflexive Habitus." The Sociological Review $5^{1}$ (4): $5^{28-549 .}$

Trites, Roberta Seelinger. 2000. Disturbing the Universe: Power and Repression in Adolescent Literature. Iowa City, IA: University of Iowa Press.

Turner, Victor. 1969. The Ritual Process: Structure and Anti-Structure. Ithaca, NY: Cornell University Press.

Van Gennep, Arnold. 19o9/196o. The Rites of Passage, translated by Monika B. Vizedom and Gabrielle L. Caffeee. London: Routledge \& Kegan Paul.

Van Meijl, Toon. 2013. "Multiple Identifications of Multicultural Adolescents: Dialogues between Tradition and Postmodernity in a Global Context." In Adolescent Identity: Evolutionary, Cultural and Developmental Perspectives, edited by Bonnie Lynn Hewlett, 203-221. New Yok: Routledge.

Wilson, Janet, Cristina Şandru and Sarah Lawson Welsh. 2010. "General Introduction." In Rerouting the Postcolonial: New Directions for the New Millennium, edited by Wilson, Janet, Cristina Şandru and Sarah Lawson Welsh, 1-14. London: Routledge.

Young, Robert J. C. 1991. "Neocolonialism and the Secret Agent of Knowledge." Oxford Literary Review 13 (1-2): 220-251.

Young, Robert J. C. 2012. "Postcolonial Remains." New Literary History 43: 19-42. 